\title{
LEGISLATION BY CONSENT IN THE MOTION PICTURE INDUSTRY
}

THE motion picture industry, only recently arrived at full stature ${ }^{1}$ after an amazingly rapid adolescent expansion, has developed a unique organizational rigidity commonly apparent only within older trades. The industry is basically tripartite in character: producers lease their product through nationwide distributors to the 17,000 exhibitors ${ }^{2}$ who serve the "consuming" public $^{3}$ throughout the country. Over the last two decades, however, some eight producing organizations ${ }^{4}$ have emerged to dominate, if not monopolize, ${ }^{5}$ the production end of the industry and to subordinate the once independent distributors to the position of licensing agents for their parent producers and such independent producers as may contract to use their facilities.

In the exhibition field there has been widespread consolidation both on at horizontal level into chains of theaters and vertically through direct affiliation of certain of these circuits with one of the five "integrated" major producers. ${ }^{0}$ The great majority of the theaters, however, have remained independent and unaffiliated. Dealings between exhibitors and the major producers, some of whose product is necessary for the survival of any theater, have developed and crystallized along lines in large degree unique with the industry. Although

1. The industry represented a total investment of approximately $\$ 2,050,000,000$ in 1939, and employed some 282,000 persons in its various branches. Morros Ptcrupts Abroad (U. S. Dep't Comm., March 15, 1940) 2-3 (hereinafter referred to as Morron Pictures Abroad).

2. In January, 1940 there were 17,003 theaters in operation in the United States with a seating capacity of $10,462,808$. There were 2,029 additional theaters not in opersition. Motion Pictures Abroad 5.

3. Industry estimates have placed average United States movie attendance in 1939 at $85,000,000$ persons per week, as against an estimated $110,000,000$ in 1930. MorroN PICTURES ABROAd 3. A recent Gallup Poll has placed weekly attendance at only $54,000,000$ per week. Communication to the Yaze Law Journal from American Institute of Public Opinion, Feb. 6, 1941.

4. Paramount Pictures, Inc., Loew's, Inc., (successor to Metro-Goldwyn-Maycr Corp.), Radio-Keith-Orpheum Corp., Warner Bros. Pictures, Inc., Twentieth CenturyFox Film Corp., Columbia Pictures Corp., Universal Pictures Co., and United Artists Corporation. The latter is, strictly speaking, a distributing company for a group of smaller producers. All the rest own their own distributing units, and the first five also own large circuits of theaters.

5. Of the 526 pictures produced in the season 1938-1939, 385 were produced by the eight major producers. Amended Complaint, pp. 14, 18, 20, 23, 27, 29, 30,32, United States v. Paramount Pictures et al., Civil Action No. 87-273 (S. D. N. Y. 1940) (hereinafter referred to as Amended Complaint).

6. Of the 16,251 theaters operating in 1938, 2,300 (the same number as in 1933) were affiliated with one of the defendants, and 3,829 were components of independent circuits as against 1,968 in 1933. Motron Pictures ABROAd 8. The concentration of power into the hands of the affiliated circuit is perhaps greatest in the first run, metropolitan theaters. See Amended Complaint, p. 56, § 131. 
the merits of the finished picture cannot be accurately estimated prior to completion, pictures have generally been sold "blind" - i.c., in advance of their production - and in "blocks" covering all or a large percentage of the contemplated production for the following season. Theaters have been roughly classified according to their merits as potential producers of revenue and by other more esoteric standards, and allotted "runs" of varying grades. Those of higher rank are allowed to exhibit the contracted pictures for a given period, then must pass on the prints of the picture to the theaters holding subsequent runs in their locality for further showing, presumably at reduced admission prices. To protect the economic value of the more expensive prior runs from cut-rate competition, a fixed "clearance" period has been established between successive runs. ${ }^{7}$ Thus by contract, and because of the limited number of competing theaters which can be economically operated in any given territory, varying degrees of exclusive exhibition monopolies have been set up in the local communities.

The history of the industry as so organized has produced continual conflict on at least two levels of action. On the one hand there has been a struggle for position and product among the competing exhibition interests, particularly between the circuits and their independent competitors. There have also been frequent battles between producers and exhibitors, punctuated by periodic efforts by one of the contesting elements to secure control over the other either through a process of actual integration, or by enforced subservience.

These conflicts have resulted in a continual stream of anti-trust prosecutions inaugurated by both private parties, claiming to have been.injured, and the Government. The suits have resulted in the virtual elimination of several of the more notorious devices of discrimination. ${ }^{8}$ Such injunctive and penal controls have been greatly circumscribed, however, by judicial holdings that many of the most dangerous practices are, in the absence of any conspiracy, legal attributes of the copyright holder's right to merchandise copyrighted articles as he determines, ${ }^{9}$ and by practical inability to meet the requirements

7. Such "protection" is also achieved by a zoning procedure by which no two theaters within a given radius are allotted the same run for the same pictures.

8. Specifically, distributor agreements with large circuits to set minimum admission prices at which subsequent run independent exhibitors were to show pictures, and to prohibit those independents from showing "double features" have been outlawed by Interstate Circuit v. United States, 305 U. S. 208 (1939), aff'g 20 F. Supp. S6S (N. D. Tex. 1938). See also Perelman v. Warner Bros., 9 F. Supp. 729 (E. D. Pa. 1935) aff'd sub nom. Vitagraph v. Perelman, 95 F. (2d) 142 (C. C. A. 3d, 1936), cerf. denied, 305 U.S. 610 (1938) (double features).

9. Gary Theater Co. v. Columbia Pictures, 2 Prentice-Hall Trade \& Industry Serv. If 27,270 (N. D. IIl. 1940) ; Rolsky v. Fox Mijdwest Theaters, 2 Prentice-Hall Trade \& Industry Serv. [27,056 (W. D. Mo. 1936). But see Gittone v. Warner Bros., 30 F. Supp. 823, 829 (E. D. Pa. 1939), rev'd on other grounds, 110 F. (2d) 292 (C. C. A. $3 d, 1940)$. 
for proof of conspiracy. ${ }^{10}$ These requirements have been greatly modified by the recent Interstate Circuit case which permits a wholly circumstantial proof of conspiracy. ${ }^{11}$ But the great costs of an anti-trust action and the extreme difficulty of enforcing any award through the complex mechanism of contempt proceedings still limit the effectiveness of this channel of relief. ${ }^{12}$ Sporadic efforts at legislative action have been no more successful in securing substantial protection for exhibitors. ${ }^{13}$

As a result of numerous complaints, the Anti-trust Division in 1938 instituted a major action in equity against the eight major producers and their affiliated interests. ${ }^{14}$ The original complaint attacked the large scale vertical integration of production and exhibition as the principal cause of restraint and monopoly in the industry, and prayed for "divorcement" of exhibition from production as the major form of relief. ${ }^{15}$ But the Government realized that at least a share of the responsibility for any of the abuses alleged to exist was traceable to the undue power of unaffiliated circuits to force discrimina-

10. See, for example, Westway Theater Co. v. 20th Century Fox, 30 F. Supp. 830 (D. Md. 1940), aff'd, 113 F. (2d) 932 (C. C. A. 3d, 1940); Rolsky v. Fox Midwest Theaters, 2 Prentice-Hall Trade \& Industry Serv. $\llbracket 27,056$ (W. D. Mo. 1936); Quittner v. Motion Pictures Producers \& Distributors of America (unreported, S. D. N. Y. 1933).

11. 306 U. S. 208 (1939), aff'g 20 F. Supp. 868 (N. D. Tex. 1938).

12. The Government has brought contempt proceedings against the "consenting" defendants under the Fox West Coast and Balaban consent decrees. Contempt proceedings were started in the former situation on Aug. 31, 1939 (No. 14048-C, S. D. Cal.), and withdrawn in November, 1940 pursuant to an agreement collateral to the major anti-trust suit, which has modified the older decree to bring it into harmony with the new decree, and specifically, to provide arbitration as a method of relief. The Balaban defendants were cited for contempt in February, 1939. 2 Prentice-Hall Trade \& Industry Serv. II 27,164 (1939). Suit was settled along with modification of the decree on December 10, 1940 by a plea of nolo contendere and fine of the guilty defendants. United States v. Barney Balaban, 2 Prentice-Hall Trade \& Industry Serv. $\llbracket 27,331$ (N. D. IIl. 1940).

13. The Motion Picture Code (Approved Code No. 124, 1933) organized under the NRA, 48 STAT. 195 (1933), was the most ambitious attempt at overall regulation, but was voided with the Act by the Supreme Court. Schechter Poultry Corp. v. United States, 295 U. S. 495 (1935). See Nrzer, New Courts of Industry (1935). The Neely Bill, which would outlaw the "block booking" and "blind selling" abuses, has been repeatedly introduced, -but though the most recent effort (S. 280, 76th Cong., 1st Sess.) passed the Senate, the bill never became law. No action has been taken on a "Divorccment Bill" (S. 3735, 76th Cong., 3d Sess.), also introduced by Senator Neely. North Dakota passed a "divorcement" Act in 1937 (Laws, N. Dak., 1937, c. 165) held constitutional in Paramount Pictures v. Langer, 23 F. Supp. 890 (S. D. N. Dak. 1938). But the statute was repealed at the next legislative term, before its effectiveness could be gauged. Laws, N. Dak., 1939, c. 202. Several other state laws have been held void, or non-applicable to the moving picture industry on grounds that such an application interfered unduly with interstate commerce. Glass.v. Hoblitzelle, 83 S. W. (2d) 796 (Tex. Civ. App. 1935) ; Paramount Publix v. Hill, 11 F. Supp. 478 (W. D. Wis. 1932).

14. United States v. Paramount Pictures et al., Civil Action No. 87-273 (S. D. N. Y. 1938).

15. Complaint, United States v. Paramount Pictures et al., Civil Action No. 87-273 (S. D. N. Y. 1938). See especially II 133, 173-198; 222-226, and Prayer, 4-6. 
tion against independent theaters, and that divorcement could not solve this aspect of the problem. ${ }^{18}$ Therefore, concurrent with the major suit, the Government brought separate actions to dissolve three of the more important unaffiliated circuits ${ }^{17}$ as a step toward complete atomization of exhibition facilities into independently owned and operated theaters.

With the announced intention of aroiding the industrial dislocation necessarily consequent upon dismemberment of the theater holdings of the defendants, ${ }^{18}$ and because of a realization that even a successful prosecution of the suit might not secure from the court the divorcement asked as the remedy, the Government has now entered into a consent decree with the five theater-owning defendants in an effort to evolve a modus vivendi short of divorcement which might sufficiently alleviate the alleged restraints. ${ }^{10} \mathrm{By}$ compromising on divorcement the Government has been able to insist on the introduction into the decree of extra-legal provisions providing primary enforcement of the mandates of the decree by arbitration, without the necessity of recourse to the difficult contempt procedure. ${ }^{20}$

The decree, as finally approved, represents a shift from an emplasis on vertical integration to a theory that the major evils in the motion picture industry stem from the abuse of the chain buying power of circuits, both affiliated and unaffiliated. This inclusion of the unaffiliated chains among the parties against whom the force of the decree was aimed, required unusual circumspection by the framers of the decree in devising forms of relief which would not interfere with the legal or contractual rights of those independent circuits not parties to the original suit. This has been achieved by directing the injunctive sections of the decree at preventing actions by the defendant distributors in dealing with the chains, and by leaving existing licenses unaffected by any award granted by the arbitrators. ${ }^{21}$ Furthermore, the chains and all other interested third parties have been granted the absolute privilege of intervening in any arbitration proceeding in which their rights are affected.?

Unlike the consenting defendants, however, the independent chains have had neither the advantage of participation in the negotiations leading to the

16. Public Statement of Antitrust Div., U. S. Dep't of Justice, April 28, 1939, p. 2.

17. United States v. Griffith Amusement Co., Civil Action No. 172 (W. D. Olla. 1939); United States v. Schine Chain Theaters, Civil Action No. 223 (W. D. N. Y. 1939); United States v. Crescent Amusement Co., Civil Action No. 54 (M. D. Tenn. 1939). In spite of the present consent decree the Government intends to proceed with the prosecution of these suits, but the consenting defendants in the New York decree have been removed as party defendants. Communication to the YaLE LAW Joun:sil from James V. Hayes, Special Assistant to the Attorney General, Dec. 2, 1940.

18. The Proposed Consent Decree, Public Statement of Antitrust Div., U. S. Dep't of Justice, Oct. 29,1940, p. 8.

19. Consent Decree, United States v. Paramount Pictures at al., Civil Action No. 87-273, (S. D. N. Y. Nov. 20, 1940) (hereinafter referred to as the Consent Decree).

20. Consent Decree $\$ 22$. See Hamilton, A Judicial Process for Indusiry (1941) 5 ARR. J. 50 ; p. $\$ 69$ infra.

21. See Consent Decree $\$ 8$ (clearance); $\$ 10$ (run discrimination).

22. Consent Decree $\$ 22(9)$. 
decree, ${ }^{23}$ nor the option of refusing the plan finally agreed upon at the risk of further suit. ${ }^{24}$ It is true that all interested parties were permitted to express their opinions of the decree to the court prior to its final acceptance. ${ }^{25}$ In the light, however, of the unwillingness and inability of courts to exercise any substantial control over the content of a consent decree agreed upon by the contesting parties, ${ }^{26}$ this unofficial right to a hearing was of questionable value, and though all persons who appeared at the hearing denounced the decree, Judge Goddard approved it without modification. ${ }^{27}$

\section{The Decree}

While the present decree probably goes further than any previouts effort of the Anti-trust Division in imposing positive methods of competition upon an industry, ${ }^{2 B}$ no "code of fair competition" in the NRA sense has been established. The provisions of the decree are not intended to eliminate competition, or to restrict it within "fair" boundaries. The aim is rather to extend competition to areas where it has previously been restricted by the play of monopoly power. ${ }^{29}$

The decree, as adopted, divides itself roughly into four main divisions. One part is designed to alleviate the evils peculiar to the licensing of pictures - particularly block booking and blind selling. This has been attempted through the adoption of mandatory provisions which forbid the licensing of pictures until they have been completed and shown for the benefit of exhibitors, and permit the licensing of them in groups of no more than five

23. Allied States Association of Motion Picture Exhibitors, an organization composed solely of independent theaters and chains, was, however, consulted by the Government during the course of the negotiations. Communication to the YaLE LAW Journal from Allied States Association of Motion Picture Exhibitors, Nov. 23, 1940.

24. They have, moreover, no standing to ask the court to vacate or modify the decree should it prove unduly burdensome in operation.

25. Hearing, Nov. 14, 1940, reported in Motjon Picture Herald, Nov. 23, 1940, $15,18$.

26. In none of the consent decrees secured by the Antitrust Division to date has the court refused to accept the proffered decree, or insisted upon any modifications in its terms.

27. Motion Pucture Herald, Nov. 23, 1940, 15, col. 1. It was admitted by the Government that no known exhibitor organization was in favor of the decree.

28. The nearest previous equivalents of an overall "code" are probably the "Auto Finance Decrees." United States v. Ford, Civil Action No. 8 (N. D. Ind. 1938); United States v. Chrysler, Civil Action No. 9 (N. D. Ind. 1938). See Isenbergh \& Rubin, Antitrust Euforcement Throngh Consent Decrees (1940) 53 HaRv. L. REv. 386, 395 ct seq.

29. This new competition would be "forced" at two different points. Exhibitors would be made to compete upon the merits of their individual theaters, at the expense of chain buying power. The major producers would be obliged to compete on the basis of their current product rather than on their past reputations. The decree also aims at freeing the market for pictures so that small independent producers can offer their product for license in a market not already preempted by prior commitments of exhibitors with major producers. 
feature pictures. Another division deals with prevention of chain discrimination in the designation of run and the fixing of clearance schedules. This has been accomplished by granting aggrieved exhibitors the privilege of arbitrating their claims. Successful exhibitors are awarded an opportunity to compete, theater-for-theater, for the preferred run, or by having a limit set on the maximum clearance allowed the holders of the prior runs. A third part of the decree is aimed at the problems of affiliation. It permits wide latitude to distributors in dealing with their aftiliated theaters, but, in lieu of divorcement, attempts to restrict further extension of the affiliated circuits. Finally, there are the various enforcement and escape clauses, the most important of which is a novel provision for independent arbitration as the primary means for enforcement of most of the decree, with resort to this mechanism delegated solely to "injured" exhibitors.

Selling Restrictions. The consent decree is frankly experimental in the procedure which has been devised to alleviate the restrictions of the "monopolistic" selling practices ingrained in the marketing pattern of the industry. Block booking, and the concomitant blind selling, ${ }^{30}$ through which all or most of a producer's annual output is licensed before production on the basis of the relative success of previous seasons' pictures, aided by whatever information can be gleaned from the annual pre-production announcements, have always been the focal points of sharp intra-industry disputes. Although wholesale marketing results in lower distribution costs, and furnishes the producer with an assured source of revenue and the exhibitor with an assured product, the quality of the product is unforeseeable. Block booking preempts most of the available exhibition outlets, thus discriminating against both independent producers ${ }^{31}$ and the exhibitors by preventing the latter from utilizing any independent picture even though superior in quality, or cheaper in price. Furthermore, while exhibitors enjoying strategic bargaining positions may be able to secure some release from "bad" pictures by insisting upon the privilege of cancelling a certain percentage of the "book," the weaker

30. Block booking, in the absence of a conspiracy among distributors, has been held legal. Federal Trade Comm. v. Paramount Pictures, 57 F. (2d) 152 (C. C. A. 2d, 1932). The court purported to see a free option in the exhibitor to purchase the entire block, or refuse it and bid for a lesser number of pictures at a later date, if the distributor has failed to sell the block to a competitor. The reality of any such option seems doubtful.

31. The independent producer of a few high quality pictures has little difficulty at present in securing a distribution outlet through one of the defendants. The decree should give a further boost to the so-called "unit" method of production, by" which major distributors release the quality product of numerous independent and semi-independent producers, as each defendant will wish to tie up as little of its own money in unsold, uncompleted pictures as is possible. The producers standing to gain by the freeing of markets, therefore, are those makers of cheaper pictures, whose major bargaining powers result from the low prices at which they can offer their pictures to exhibitors. It is these marginal producers who will be known as "independent producers" throughout this Comment. 
independent exhibitors may not be able to obtain such privileges. ${ }^{82}$ Finally, block booking has promoted the serious abuse of "overbuying," by which a theatre has been able to lease at one time more pictures for the following year than it needs or will use, thus depriving weaker competitors of any source of quality production.

The mandatory elimination of wholesale blind selling incorporated into the decree goes far towards a revolution in the techniques of licensing. This has been done, in part, by requiring a formal trade showing prior to licensing of any pictures. ${ }^{33}$ Thus in one move a shift has been effected from a seller's market in which exhibitors customarily leased their product sight unseen or received no pictures from the major producers, to what is, if not a buyer's market, at least one where both parties to the contract are fully informed as to the content and probable value of the subject matter. In the interest of retaining some of the admitted savings of large scale marketing, individual licenses for each picture have not been required. ${ }^{34}$ Insteal a "compromise" has been developed by which completed feature pictures may be leased in groups of five or less after they have been "trade shown." ${ }^{35}$ No license of one group is to be conditioned upon the lease of any other, but an exhibitor may purchase as many blocks as are completed and available at any given time. ${ }^{38}$

It is hoped and expected that the shift from reliance upon past records and future promises to competition for known current procluct will result in a better average quality of pictures. Certainly a more even distribution of quality productions throughout the season is to be expected. While blocks of five will permit the inclusion of a certain number of " $B$ " pictures in every grouping, all blocks offered for lease will have to contain a minimum of finer pictures, or sell in competition with independent products at greatly reduced prices. ${ }^{37}$ With exhibitors constantly in need of additional features, inde-

32. But in the last few years, with the threat of the Government's suit hanging over the industry, all but the weakest independents have secured some cancellation privileges. The almost unanimous opposition of independent exhibitors to the decree is largely motivated by fear of losing these concessions. See Report of the Nov. 14 hearing. Morton Picture Herald, Nov. 23, 1940, 15, 18. See also Brief for Independent Theater Owners Ass'n of New York, Intervenors, p. 5, United States v. Paramount Pictures at al., Civil Action No. 87-273 (S. D. N. Y. 1940) ; Motion Picture Theater Owners of America, General Bulletin, Nov. 26, 1940, p.7.

33. Consent Decree $\$ 3$.

34. Stated to be the "ideal solution" by James V. Hayes, Special Assistant to the Attorney General, at hearing, Nov. 14, 1940. Morton Picture Herald, Nov. 23, 1940, 15, col. 3 .

35. Consent Decree $\$ \S 3,4(a)$.

36. Consent Decree $\$ 4(\mathrm{a})$.

37. As the inclusion of cheaper product in a block will tend to detract from the value of the better " $A$ " pictures, upon which the greater percentage of profit is made, companies might find it more profitable to organize two series of blocks, one containing the "specials," and the other the cheaper product. If this were to occur, the blocks 
pendent producers will have a chance to find a market for their productions. Small exhibitors, hitherto restricted to playing the pictures of the lesser producers, may now be able to compete for at least some of the pictures of the more successful producers. The exhibitor willing to back his judgment of the merits of any particular picture or block will be able to lease it without the necessity of outbidding his stronger competitors for the producer's entire annual product. Exhibitors catering to a unique or superior clientele will similarly have a better chance to secure those pictures peculiarly appealing to their patrons.

Limitation of licensing to blocks of five pre-shown features should also help to curtail the practice of overbuying. No exhibitor will be able to preempt all of the year's supply of quality pictures prior to their production, and while it still might be possible to lease all of the features offered at any one time, ${ }^{38}$ an exhibitor undertaking such a maneuver must be willing and able to pay more for every block offered than his competitors can pay for any of the blocks or pictures. The effect of the new selling procedure is, however, highly speculative, and it seems overly sanguine to believe that the decree has necessarily eliminated all overbuying. Though the "selective annual contract" device will be eliminated, ${ }^{39}$ it will still be possible to achieve a similar result through unnecessarily frequent changes of program.40 And exhibitors will be able to undertake short term "squeeze plays" without incurring full year commitments. Thus the elimination of special arbitration provisions for claims of overbuying from the final draft of the decree would seem to be premature. ${ }^{\text {i1 }}$

of "Bs" would probably seek their own level of competition with each other, and with the product of the "independent producers."

38. Consent Decree \$4(a).

39. By this method of overbuying, the exhibitor contracted before exhibition for far more product than he could utilize, with the understanding that he need talse and pay for only some specified fraction.

40. The NRA Moving Picture Code recognized "too frequent changes" of program as one of four types of "overbuying" subject to arbitration before loeal Grievance Boards. Approved Code No. 124, Art. VI, Pt. 2, $\$ 1$ (b) (1933). It is probably the most frequent method of overbuying because of the extreme difficulty in showing that the policy was in fact instituted as an overbuying device, rather than as an ordinary business practice. The NRA Grievance Boards were surprisingly successful, however, in working out rules of thumb to combat the practice, and many victims received proper relief. Nizer, New Courts of Industry (1935) 30-35.

41. The draft of the decree proposed by the Department of Commerce allowed exhibitors to lease at one time no more pictures than would be sufficient for $a$ four months supply, and provided for arbitration of all complaints of overbuying. Proposat. FOR A CONSENT DeCreE (U. S. Dep't of Comm, 1940) $\$ 5(\mathrm{~b}$ ), quoted in full in VARIETY. May 1, 1940, 13, col.1. See also the plan set out in the proposed Trade Practice Code of $1939, \$ 14(3)$, quoted in full in Hearings before Commitlee on Interstate Commerce on S.280, 76th Cong., 1st Sess. (1939) p.217. The difficulty of fixing a limitation on the number of blocks leasable at one time, may have been partially responsible for the absence of any section providing for arbitration. 
There appear to be several dangers inherent in the plan of licensing, other than the general uncertainty resulting from the substitution of numerous competitive licensing periods for the assurance of annual contracts. A greater amount of time will have to be given over to the leasing of pictures.22 There will be a certain increase in distribution costs, which must be absorbed by the exhibitors or distributors, or eventually lead to higher public admission prices. ${ }^{43}$ More important is the grave possibility that the new selling system might discriminate particularly against the very group of small independent exhibitors which the decree intends to assist. No cancellation privileges have been included in the decree, the position of the Government being that cancellation must remain a question for private bargaining.44 Though it is certain that all distributors will be unwilling to grant any extensive cancellation from a block of only five pictures, it is likely that the exhibitors in the strongest competitive positions - the circuits and local monopolies - will be able to lease pictures individually or in smaller groups than the standard. The weaker independents, however, faced with the constant uncertainty of securing adequate product to meet their more frequent changes of program, have objected that in many cases they may have to license blocks without the possibility of securing cancellation privileges. ${ }^{45}$ This group, therefore, might have been more advantageously situated under the terms of the voluntary Trade Practice Code, unsuccessfully proposed in 1939, which would have guaranteed the weakest of their number a twenty per cent cancellation

42. In spite of persistent exhibitor claims to the contrary, this does not include the time and expense of periodic trips to exchange headquarters to attend the trade showings. $\$ 3$ of the decree does not make attendance at the trade showings mandatory, and it is to be expected that most exhibitors will get their information about the merits of the pictures screened from reviews in the trade press or through specially appointed agents in attendance at the showings.

43. Sales by smaller blocks not only involves a necessity of more numerous selling seasons, and larger distribution staffs, but may also force a great increase in unprofitable working capital. As pictures cannot be sold until "trade shown," unless distributor and exhibitor are willing to go to the added expense of selling pictures individually as completed, five or more pictures will have to be financed in advance of sale, without the usual security of signed contracts. This may not interfere greatly with the larger integrated companies, but it imposes a serious burden upon the smaller defendants, and is one of the more important reasons for Columbia's non-adherence to the decree. Brief of Columbia Pictures Co., in opposition to the Proposed Consent Decree, pp. 5-6, United States v. Paramount Pictures et al., Civil Action No. 87-273 (S. D. N. Y. 1940).

44. The Proposed Consent Decree, Public Statement of Antitrust Div., U. S. Dep't of Justice, Oct. 29, 1940, p. 4 .

45. While the first run metropolitan theater can often get along with one picture per week or less, the smaller subsequent run "houses" usually require from four to six different pictures. Where the latter policy is in effect, requiring a minimum of 312 pictures, the question of cancellation may become relatively unimportant next to the necessity of securing an adequate supply of films of any nature or kind. These theaters may thus be hurt more by the necessity of constant purchasing in small groups, without the certainty of annual contracts guaranteeing sufficient product, than by the elimination of theoretical cancellation privileges. 
privilege. ${ }^{46}$ It may well be that certain definite advantages are to be achieved by the breakdown of the blocks in which pictures are now offered for lease, but it might have been wiser if this process had been limited to allow the license of blocks of eight or ten features, with the exhibitor granted the privilege of cancelling one or two from each group.

Further discontent with the terms of the selling provisions stems from the inclusion of a proviso permitting distributors to vary the announced contents of blocks after they have been offered for lease. ${ }^{47}$ This flexibility may be necessary to allow differentiation in the blocks to suit the special needs and desires of varying regions and of theaters catering to a peculiar clientele. But it is clear that it provides an additional chance for discrimination by a distributor in favor of a powerful circuit by offering better blocks to the favored purchasers.

Unlike the bulk of the decree which is permanently established, ${ }^{15}$ subject to the usual liability to modification where change of conditions leaves the original provisions useless or needlessly harsh, ${ }^{\text {t0 }}$ the selling requirements have been put on only a temporary basis. ${ }^{50}$ If the Government fails in its efforts to impose similar terms upon the non-consenting defendants, ${ }^{, 1}$ if competition from independent producers advances beyond a certain fixed percentage of the total market, or "substantially and adversely" affects the business of the "big five," or if state or federal legislation of a similar nature supervenes, the consenting defendants may move to vacate the relevant sections of the decree. ${ }^{52}$ While it is questionable whether the Government can secure similar concessions from the unwilling "little three," $" 3$ failure in this effort will not

46. Trade Practice Code $\$ 1$, quoted in full in Hearings before Conmiltec on Inferstate Commerce on S.280, 76th Cong., 1st Sess. (1939) p.218.

47. Consent Decree $\$ 4(a)$.

48. Section 11 of the decree providing a limitation on purchase of new theaters by defendants, is limited absolutely to three years. Consent Decree $\$ 11(1)(5)$. Presumably this is related to the three year period in which the Government will not move towards divorcement. Consent Decree \$21. But as the latter section imposes no obligation of action at the end of the three year period, it would seem that $\$ 11$ might have been given a more flexible time limit.

49. Consent Decree $\$ 23(d)$, (e). Modification may also be secured to comply with state or federal laws. At least one opponent of the decree - the Allied Theater Owners of the Northwest - has already taken action to force a modification of the decree through introduction of conflicting state legislation. Communication to the YALE LAW Joumsar. from Allied Theater Owners of the Northwest. Dec. 16, 1940.

50. See Consent Decree $\$ 12$.

51. Columbia, Universal, United Artists.

52. Consent Decree $\$ 12$. Or if the Government secures similar, but difiering, selling provisions from the non-consenting defendants, the five consenting defendants may, at their option, adopt for themselves the new provisions. Consent Decree $\$ 12(\mathrm{c})$, (d). The section is a sharp limitation upon the extent to which "independent producers" may" hope to benefit from the decree, by remaining outside and offering exhibitors a chance to secure a percentage of their product in advance by the annual contracts.

53. See p. 873 infra. 
necessarily result in automatic reversion to compulsory block booking. For defendants realize that unless the Government is also willing to abandon the entire experiment, a unilateral regression to the old practices might induce the Government to further efforts towards divorcement, or, as a direct substitute for the blocks of five, stricter limitation of all circuit buying powers. ${ }^{54}$

The decree attempts, with varying degrees of success, to abate certain other selling abuses. In a direct effort to limit the purchasing power of the larger nationwide circuits - for the most part those affiliated with the consenting defendants - group licensing is limited to theaters in the same selling territory, or "exchange district." 55 This means that Paramount, for example, which controls theaters throughout the country, will no longer be able to lease pictures for all of them in one transaction. The restriction can be expected to have little effect upon the individual theater owner but will place the independent regional chains on a bargaining par with their larger but less concentrated competitors. Other provisions, of uncertain effectiveness, , $^{\text {b0 }}$ allow exhibitor arbitration where "shorts" or "foreigns" have been or are about to be forced on exhibitors as a condition of licensing requested features. ${ }^{57}$ Finally, exhibitors have been granted an absolute right to cancel pictures they consider "morally, religiously, or racially offensive" to their communities. ${ }^{58}$

Run and Clearance Provisions. Among the more constructive achievements of the decree are the provisions devised to prevent discriminatory abuse of run and clearance designations, probably the most important single factors in deciding the ultimate success or failure of a theater. ${ }^{50}$ The legality of these practices has long been established, ${ }^{60}$ and their necessity in the current

54. This might be possible only three years after the effective date of the decree. See Consent Decree $\$ 23(d)$.

55. Consent Decree $\S 5$.

56. See note 100 infra.

57. Consent Decree $\S 4(\mathrm{~b})$. "Shorts" include newsreels, advertising trailers and serials; "foreigns" include reissues, and "westerns" - inexpensively produced "horse operas." As none of these is limited by the block of five or trade showing restrictions, it is probable that they will be sold, as now, in blocks before production. Should this prove so, they will be more difficult to "force" as a condition of leasing a block of features which cannot be licensed until trade shown.

58. Consent Decree $\$ 7$. The effectiveness of the provision is limited in that the exhibitor must complain within ten days of receiving the signed license. This may be before public showing, so that actual local reaction cannot be gauged. The picture will have been trade shown, however, giving the exhibitor an opportunity to examine the picture himself.

59. See p. 855 supra.

60. Westway Theater v. 20th Century Fox, 30 F. Supp. 830 (D. M(l. 1940), aff'd, 113 F. (2d) 932 (C. C. A. 3d, 1940) (clearance); Peoples Film Co. v. Minnesota Film Board of Trade (unreported, D. Minn. 1932) (clearance); Gary Theater Co. v. Columbia Pictures, 2 Prentice-Hall Trade \& Industry Serv. $\llbracket 27,270$ (N. D. Ill. 1940) (clearance and run). 
system of distribution unquestioned. Yet the overbearing strength of circuit bargaining power has markedly influenced the choice of theaters to be granted prior exhibition franchises, and resulted in the establishment of unnecessarily extensive clearance periods between successive runs. Not only have physically inferior theaters been given advantages over superior independents, but they have been granted such advantages while paying no more or even less for the individual licenses than an independent exhibitor would have been willing to pay.

In the absence, however, of a conspiracy among distributors, run was, prior to the decree, a problem exclusively determined by negotiation between the distributor and the various competing exhibitors, with the distributor having the ultimate right to dispose of his copyrighted pictures as he saw fit. ${ }^{61}$ This was likewise true of clearance determinations, except that unreasonable clearance granted by a distributor to any exhibitor over subsequent run theaters might have been an illegal conspiracy between the distributor and the beneficiary exhibitor. ${ }^{62}$ And, of course, in the few instances in which conspiracy could be proved, the effectiveness of the available injunctive relief was limited by the necessity of enforcement through contempt proceedings. ${ }^{.3}$

In the consent decree the powers of the chains have been sharply limited. Independent exhibitors have been given the right of arbitration to force a comparative analysis of the individual merits of the various theaters claiming a particular run. Complete divorcement of the "guilty" theater from the circuit for purpose of future bargaining is the penalty imposed upon any exhibitor found guilty of holding a run due to chain favoritism. ${ }^{\text {ot }}$ The section makes no attempt at artificial balancing of specific buying power - the arbitrator must consider the "terms" offered by the disputing exhibitors along

61. See note 9 supra.

62. With the exception of Youngclaus v. Omaha Film Board of Trade, 60 F. (2d) 538 (D. Neb. 1932), which voided as an illegal conspiracy the general clearance schedule drawn up for the Omaha territory as an outgrowth of the Standard Eshibition Contract, no private suit has to date secured clearance relief. On the other hand, two Government suits against the Fox West Coast Theaters and one against the Balaban \& Katz interests of Chicago have resulted in consent decrees achieving by judicial fiat the regional clearance schedules held illegal when privately imposed. See United States v. West Coast Theaters (unreported, S. D. Cal. 1930); United States v. Fox West Cosst Theaters (unreported, N. D. I11. 1932) ; United States v. Balaban \& Katz Corp. (unreported, N. D. Ill. 1930). The rationale of the Interstate Circuit case, however, now permits a showing of a vertical conspiracy between one distributor and the beneficiary exhibitor. Interstate Circuit v. United States, 306 U. S. 208 (1939).

63. See note 11 supra.

64. Consent Decree $\S 10 \mathrm{D}$. By not granting the run outright to the vinning complainant, the possibility of future unfair rigidity has been avoided, and the ideal of constant run competition approximated. By granting both winning and losing exhibitors the right to demand supplementary arbitration should continued favoritism or changed conditions make the adjusted situation still inequitable, the provision is largely selfenforcing. Consent Decree $\S 10 \mathrm{E}$. 
with other factors in arriving at his decision. ${ }^{65}$ The section does insure, however, that henceforth no circuit theater will be able to hold a prior run against the claims of a superior independent theater able to pay an equivalent price, merely because of its chain membership.

Unfortunately, the qualifications for suit under the run provisions of Section 10 are so restricted that it is questionable what percentage of exhibitors will be able to take advantage of its opportunities. Only those exhibitors are permitted to arbitrate whose theaters were in existence at the date of entering the decree, ${ }^{66}$ and who, by written complaint to a distributor or the Department of Justice, ${ }^{67}$ demanded a better run prior to July 20, 1940. ${ }^{.88}$ This discrimination against exhibitors, who may have failed to register otherwise valid claims in the subsequently prescribed manner, has been justified to prevent swamping the arbitration machinery by claims of exhibitors willing to risk the relatively slight costs of arbitration in an eftort to win a superior run worth thousands of dollars to the holder. Similarly, the restriction of claimants to existing theaters or their replacements has been held necessary to prevent a rash of building activity by real estate speculators, who would be able to force existing theaters to buy them out or risk the loss of their established run positions. While this may be a valid reason for the limitation, favored affiliated chains, unhampered by the mild restrictions on further expansion found in the decree, ${ }^{60}$ can still be granted unassailable first run preferences for their better new "houses." On the other hand, those independent exhibitors who build superior new theaters will still be in danger of assignment to inferior, profitless runs.

On the basis of a questionable theory that circuits of any reasonable size can fend for themselves, the section also permits only independent exhibitors, defined as those interested in no more than five theaters, to arbitrate run claims, and then only if the theater holding the contested run is affiliated with a circuit of at least fifteen theaters and the favoritism can be shown to result from the circuit affiliation. ${ }^{70}$ Thus not only are all of the smaller chains -

65. Consent Decree $\$ 10 \mathrm{C}$. Among other items to be considered are the distributor's prior relations with each of the theaters involved (which might favor the theater holding the run), the moral and financial qualifications of each claimant, the past and contcmplated management policies of each party, the physical equipment and location of the theaters. Claimants will probably have to show a demonstrably superior claim to the run to emerge victorious from the hearing.

66. Or whose theaters replace theaters existing at the entry of the decree. Consent Decree $\S 10 \mathrm{~A}$.

67. Consent Decree $\S 10 \mathrm{~B}(5)(c)$ and (d). Or who had filed complaints with local Grievance or Clearing \& Zoning Boards under the NRA, which had not been finally disposed of.

68. Also, exhibitors who, at any time between July 20, 1935 and July 20, 1940, or for any two consecutive motion picture seasons thereafter, enjoyed a run equal or superior to that held by the circuit theater specified in the complaint. Consent Decree $\$ 10 \mathrm{~B}$ (5) (a) and $(b)$.

69. Consent Decree $\S 11$.

70. Consent Decree $\$ 10 \mathrm{~A}, \mathrm{~B}(3)$. 
which often have the greatest grievances against run discrimination - prevented from utilizing the decree, but the entire run problem has been limited to a question of chain discrimination. ${ }^{71}$ Under the circumstances, it is probable that many exhibitors with valid claims will be forced to fall back upon the unsatisfactory alternative of bringing a direct conspiracy action in the courts.

The decree is more successful in solving the problen of those few exhibitors who have been refused product on any run or at any terms. By Section 6 they are assured of pictures on some run to be designated by the distributor, unless the latter can show that such a license would reduce his total revenue in the particular competitive area. ${ }^{72}$ Any proof of diminution of receipts seems unlikely unless there has been a threat by existing theaters to boycott the distributor's product should he grant the additional run. Such a showing would very possibly bring both the distributor and the boycotting exhibitor within the proscriptions of the Sherman Act as participants in a conspiracy to restrain the trade of the complaining exhibitor. ${ }^{73}$

Unlike the narrower run provisions, the rights to arbitrate unreasonable clearance are available to all aggrieved exhibitors free of any prerequisites. ${ }^{\text {it }}$ There is no question that some clearance must be granted if the present system of staggered runs is to be maintained, but unsupervised clearance rapidly changes from legitimate protection of a run to direct interference with the rights of the subsequent run exhibitor. Under Section $S$ of the decree the extent of all contractual clearance is made subject to challenge, with the arbitrator entitled to set maximum future "protection" after examination of the claims of the two exhibitors according to standards set by the decree. ${ }^{75}$ These specifically forbid consideration of any affiliation of

71. Consent Decree $\$ 10 \mathrm{~B}(6)$. Any other reason for discrimination or favoritism, including affiliation, in the absence, as here, of a holding that such affiliation is illegal, might be legal and beyond the reach of the anti-trust laws.

72. Consent Decree $\$ 6$.

73. See Interstate Circuit v. United States, 306 U. S. 208, 227, 228, 230 (1939). The decree also provides against withholding available prints from one of two exhibitors competing upon the same run, in order to give the other an unauthorized prior playing date. The provision is weakened, however, in that the section has no application when "too few" prints are available; the distributor is permitted full discretion to choose the favored theater. Consent Decree $\$ 9$.

74. Arbitration of clearance was previously attempted, with no great popular success, by the Clearance and Zoning Boards of the NRA Code See NIzER, New Courss of INDUSTRY (1935) 104. In that instance, however, arbitration was used only as a desperate effort to salvage something from the debacle of prior attempts to define and declare rigid overall clearance schedules for each competitive territory, and the arbitration was further handicapped by the mutual suspicions of the bi-partisan tribunals. Id. at 98107. Despite these handicaps, of the 289 cases brought before Clearance \& Zoning Boards in the first eight months of operation, 118 were decided for the claimants, and, on appeal to the Code Authority, the local Boards were upheld in $82 \%$ of the cases. Id. at 131-132.

75. Consent Decree $\$ 8$. Unlike the standards for run arbitration (Consent Decree $\S 10 \mathrm{C}), \S 8$ fails to instruct the arbitrator to consider the proposed as well as the past 
either theater. ${ }^{70}$ The clearance provisions, moreover, have been specifically made applicable to the otherwise exempted long term franchise agreements existing at the effective date of the decree. ${ }^{77}$

Affiliated Theaters. Though perhaps the major portion of the decree is concerned with the abuses of circuit operation, the problem of affiliation has not been ignored. It is probable that producer ownership or control of exhibition facilities for marketing of their own pictures is legal, and that, in the absence of a showing of discriminatory use of the powers appurtenant to such integration, it is impossible to achieve divorcement. ${ }^{78}$ In any event divorcement has not been pursued. The threat of future moves in that direction has proved insufficient to secure inclusion in the decree of any restrictions upon the intra-company dealings of the consenting defendants. Instead, the defendants have been specifically exempted from any compliance with the terms of the decree in dealing with their own theaters. ${ }^{70}$ This leaves the affiliated theaters in a relatively strong bargaining position. They start with a back-log of their own product, and consequently, under the more restrictive terms of the decree, must compete for only the few outside pictures that may be necessary to fill out their program schedules. ${ }^{80}$ Moreover, the exemption gives the theater-owning producers the advantage of starting the production season with a definite amount of assured reventue, a factor which may have contributed to the rejection of the decree by the nontheater-owning defendants. The exemption applies only to a producer's own theaters, however, and the terms of the decree make impossible the previous practice of mutual interchange of favors between the different affiliated chains, by which circuits received concessions from other producers in filling out that part of their program not appropriated by their own product. $^{81}$

The decree, moreover, attempts to place a ceiling upon further expansion of the affiliated circuits through an undertaking by the defendants to indulge

operating policy of the theaters. Thus, unless liberal arbitrators read an equivalent phrase into $\S 8$, there is a danger that complainants might be handicapped by practices adopted primarily because of their unfair clearance position.

76. Ibid.

77. Ibid.

78. Presumably, in the absence of monopoly, there is nothing per se illegal in complete vertical integration. United States v. Winslow, 227 U. S. 202, 217 (1913); cf. United States v. United States Steel, 251 U. S. 417 (1920) ; Handler, Industrial Mergers (1932) 32 Col. L. REv. 179, 236. But cf. United States v. Reading Co., 253 U. S. 26 (1920).

79. Consent Decree $\$ 17$.

80. The five theater-owning defendants distribute an average of $40-60$ features per season. See Amended Complaint, pp. 14, 18, 20, 23, 27. This might possibly meet the requirements of a few metropolitan first run theaters, with a policy of single features changed weekly or less, but will prove utterly insufficient to meet the requirements of the more typical chain theater showing from two to four features per week.

81. See Amended Complaint, p. 52, \ 125 
in no program of "general expansion." 32 The effect of the injunction, however, is strictly limited. Individual theaters may be built or acquired to maintain either the producer's competitive position or "for ordinary purposes of its business." 83 New chain theaters are not deprived of the power to bargain as full members of the circuit. ${ }^{84}$ It is true that any new chain theater will have to be superior in its physical equipment to any existing independent theater in the same territory, or be willing to accept a subsequent run. ${ }^{85}$ But there is little reason to believe that the subsequent builders will not be able to design better theaters. Furthermore, inasmuch as the decree provides no restraint on so-called "distress selling," 86 it is probable that the mere threat of building will force uncooperative exhibitors to sell their theaters to the circuit. ${ }^{87}$

\section{ENFORCENENT}

From the standpoint of development of anti-trust law, perhaps the most significant single feature of the decree is the delegation of its primary enforcement to an independent arbitration tribunal under the aegis of the experienced American Arbitration Association. ${ }^{83}$ Power to invoke this remedy rests solely with exhibitor complainants not party to the original anti-trust

82. Consent Decree $\S 11$.

83. Consent Decree $\$ 11$. Theaters may also be required to protect a defendant's "investment." Unlike other divisions of the decree, no arbitration is provided for violation of these provisions. Instead, direct application must be made to the court for injunctive relief.

84. Such was the suggestion of an earlier drait for a consent decree in the suit. See Proposal for a Conseati Decree (U. S. Dep't of Comm., 1940) $\$ 7$, quoted in full in VARIETY, May 1, 1940, 13, col.1.

85. See discussion of the "run" restrictions of $\$ 10$, supra p. 865 .

86. Such threats to build in competition with an existing exhibitor in order to blackmail him into surrendering control of his theater to the affiliated chain, were specifically denounced in the original complaint. The liberal attitude of the decree towards future theater expansion by defendants has been justified as necessary to allow just such threats to break the monopoly control of independent local exhibition monupolies. The producer defendants, however, seem better able to protect themselves than are the weaker independents, who are thus left at the mercy of the defendants.

87. On the other hand, $\$ 11(1)$, (2) impose upon all defendants the duty of keeping the Department of Justice informed of all theater acquisitions, and all relevant data of monthly changes in their "theater positions." Such information is confidential but an and will be utilized by the Antitrust Division in deciding upon possible future action. It thus should serve as a definite deterrent.

88. Attacks have recently been made on the arbitration machinery because of its supposedly ignorant "outside arbitration." Ifotion Picture Theater Owners of America, General Bulletin, Nov. 26,1940 , p.2. Such arguments seem hardly justified in viev of continuous suspicions which have accompanied "bi-partisan" attempts at arbitration in the industry. See Lewrs, THE Motron Pictune Industry (1933) 71-93 (arbitration under the Standard Exhibition Contract); Nrzer, NEw Courss of Imousmy (1935) 103, 134 et seq. The American Arbitration Association, moreover, has a long record of coming in successfully to police industries whose peculiar trade practices were at first unknown to the Association. 
action or in any way bound by the contents of the decree. ${ }^{80}$ By this procedure, ${ }^{90}$ the prohibitions of the typical anti-trust injunction which are usually difficult to enforce, have been converted into working devices for the protection of interests previously victimized by the various abusive practices. Without the inclusion of such a mechanism, efforts at relief short of complete divorcement could hardly have been effective in the face of a necessity of enforcing each violation by arduous and time-consuming contempt proceedings.

It is questionable whether such arbitration could have been imposed upon losing defendants if the Government had won its suit. The Sherman Act gives the courts power to enjoin or otherwise prohibit illegal practices and it might be doubted if this could be extended to allow for organization and operation of arbitration machinery. ${ }^{01}$ But the use of the consent mechanism has apparently obviated these difficulties. ${ }^{02}$

Under the decree only the defendants who have consented to the arbitration procedure are obligated to arbitrate all claims brought against them. The right to initiate arbitration proceedings is unilateral and can be invoked only by aggrieved exhibitors; yet no such exhibitor is compelled to arbitrate any dispute which he elects to try directly in a legal proceeding under the antitrust laws. ${ }^{93}$ If the exhibitor decides to arbitrate, however, he will be allowed to do so only if he agrees in advance to accept the award of the tribunal.04

89. Arbitration is provided to settle all claims of violation of the Act other than those arising under $\$ 11$ (see note 83 supra), and the prohibition of $\$ 5$ against including theaters located in different exchange districts in licenses of theaters of any one district. The machinery for arbitration is set out in some detail in $\$ 22$, and in the more elaborate Rules of Arbitration and Appeals, filed with the decree. See Warburg, Administration of the Motion Picture Arbitration System (1941) 5 ARB. J. 42.

90. Arbitration is not new in the Motion Picture Industry. It was first instituted on a compulsory basis as a means for the enforcement of the Standard Exhibition Contract, which was held illegal because violation of the arbitration provisions by any exhibitor led to a mandatory boycott against him by all distributors. United States v. Paramount Famous Lasky Corp., 34 F. (2d) 984 (S. D. N. Y. 1929), aff'd, 282 U. S. 30 (1930). But cf. M-G-M Distributing Corp. v. Dewitt Development Corp., 150 Misc. 408, 269 N. Y. Supp. 104 (Sup. Ct. 1931), aff'd, 273 N. Y. Supp. 444 (4th Dep't 1934) (arbitration contract valid where third party enforcement not contemplated). A more extensive arbitration development was instituted under the NRA Moving Picture Code, Art. VI (Approved Code No. 124, 1933), but fell apart upon the demise of the NRA after the Schechter case. Schechter Poultry Corp. v. United States, 295 U. S. 495 (1935).

91. 26 STAT. 209 (1890), 15 U. S. C. $\$ 4$ (1934). While "otherwise prohibit" has never been extended to include the organization of intermediate, extra-legal enforcement agencies, however, it is possible that it might be, and the Government's Amended Complaint asks the court to establish an arbitration system "to secure adequate enforcement" of the prohibitions of illegal practices. Amended Complaint p. 80 .

92. Swift \& Co. v. United States, 276 U. S. 311 (1928).

93. Claimants still have the option of ignoring the decree, and suing for triple damages under the general provisions of the anti-trust laws. The Proposed Consellt Decree, Public Statement of Antitrust Division, U. S. Dep't of Justice, Oct. 29, 1940, p. 8.

94. Consent Decree $\$ 22(a)$. 
Not only have the legal interests of the immediate parties to the arbitration been fully protected, but the rights of all other persons, directly or indirectly affected by any arbitration hearing, have been similarly secured. They have been granted the absolute privilege of intervening to become a party on agreeing to abide by the arbitrator's decision. ${ }^{05}$ Furthermore, the awards, where violations of the decree have been indicated, have been carefully drafted so as not to interfere with existing contract rights of any such outsiders. Both clearance and run awards have been made operative only in respect to subsequent contracts. ${ }^{88}$ No private enforcement of any nature is prescribed for violation of the prohibition against licensing pictures to circuit exhibitors for theaters located in more than one exchange district. ${ }^{97}$ On the other hand, where run discrimination has been shown, the award, "divorcing" the "guilty" theater from its circuit for purposes of all future contracting, operates directly against the exhibitor recipient of the favoritism without seriously affecting the position of the defendant distributor. ${ }^{29}$

While arbitration, as a general method of enforcement seems highly advantageous in the present situation, a serious problem is raised by the time lags and risk of expense inherent in the organization of the particular arbitration scheme proposed in the decree. It is axiomatic that the possible awards must warrant the risk of loss or exhibitors will not resort to arbitration. The great gains achievable in any successful proceeding, and the improbability of securing sufficient or rapid relief through direct court action, insure against any paucity of clearance or run actions; but the same cannot be said of certain lesser rights "guaranteed" by the decree. It is doubtful whether exhibitors can be expected to risk the burden of costs of arbitration ${ }^{03}$ where a distributor has illegally conditioned the licensing of pictures to theaters in one exchange district upon the simultaneous licensing of the pictures for theaters located in other exchange districts, since the distributor, if found guilty, must merely pay a nominal sum into the general arbitration fund, and the complaining exhibitor receives no direct relief. ${ }^{100}$ Similarly, the

95. Rules of Arbitration and Appeal, $\$ 1$; Consent Decree $\$ 22(a)$.

96. Consent Decree $\S \S 8,10 \mathrm{D}$.

97. See Consent Decree $\$ 5$. It is not clear why defendants violating this provision should not at least be fined as are distributors illegally conditioning a license upon the leasing pictures for exhibition in theaters outside the exchange district. It may have appeared to the drafters of the decree, however, that as no one private party would be particularly injured by violation of the Section, it would be better to allow such a violation to be penalized by direct contempt action by the Government.

98. Consent Decree $\S 10$ (d).

99. It has been estimated that the total costs of the preliminary regional arbitration will be $\$ 75$ as an average maximum, payable by the losing party, or apportioned among the parties by the arbitrator (Rules of Arbitration \& Appeal $\$ 10$ ). Average appeal costs, payable by the party taking the appeal unless otherwise apportioned by the Appeal Board (Rules of Arbitration \& Appeal $\$ 17$ ), have been estimated at $\$ 300$. Wall Street Journal, Dec. 2, 1940, p. 3, col. 2.

100. Consent Decree $\$ 5$. This also is true of arbitration proceedings undertaken prior to entering into a license, where a claim of violation of the restrictions against 
"right" to cancel short subjects, offensive pictures, or additional blocks of features forced on the exhibitor as a condition to the lease of other desired features, is of doubtful value if the primary arbitration may extend well over a month before any opinion is announced. ${ }^{101}$ As no exhibitor can be expected to wait for a month prior, to discovering what pictures he has available for playing, it would seem advisable to amend the arbitration rules to provide for expedited hearings of such "forcing" cases. In other instances the award may have to be made more appealing to the exhibitors; or the Government be given power to invoke the arbitration machinery.

While the arbitration machinery and rules are still in only skeleton form, and will have to be amended and expanded from time to time according to the provisions of Section 22(6), the most important technical problem remaining to be clarified is the ultimate enforcement of final arbitration awards. ${ }^{102}$ Presumably such enforcement would be through application to the court for a citation of contempt against the non-conforming party. ${ }^{103}$ But whether such an application against a consenting defendant must be brought by the Government as one of the parties to the decree, or by the exhibitor who made the original complaint, is yet to be decided.

Although the Government has delegated the primary enforcement of the terms of the decree to complaining exhibitors, and postponed for the time being any further action leading towards divorcement, ${ }^{104}$ it has not dissociated itself entirely from the operation of the decree or the control of restraints in the industry. Instead, a permanent sub-division has been organized in the Antitrust Division to supervise the workings of the decree and determine the necessity for future Government action. ${ }^{105}$ This group is aided by requirements in the decree that written notice be sent to the Division of all changes in theater ownership or control by the consenting defendants, ${ }^{100}$ and by permission granted the Government to examine on demand the books and documents of the defendants relevant to the decree, including complete data on trade showings, licenses contracted, and records of all arbitration

selling in blocks of more than five pictures or of forcing "shorts" or "foreigns." Consent Decree $\$ 4(\mathrm{~b})$.

101. Under the provisions of Rules 3 and 5 it is impossible to start a hearing on a claim in less than 21 days, and a dilatory defendant may extend this time by at least six days by failing to agree in advance to the appointment of agreed-upon arbitrators. Then, regardless of any possible prolonged hearing, the arbitrator is given 30 days in which to make his final decision. Rules of Arbitration \& Appeal $\S \S 3,5,10$.

102. The court has retained jurisdiction necessary for "construction" of the decree. Consent Decree $\S 23(a)$. There is thus a danger that the entire arbitration machinery may be side-stepped, through constant resort to the court to secure constructions of the decree which presumably would be binding upon the arbitrators, and overrule any contrary holding.

103. Consent Decree $\$ 23(\mathrm{a})$.

104. Consent Decree $\$ 21$.

105. Motton Picture Herald, Nov. 2, 1940, 13, col. 1.

106. Consent Decree $\S 11$. 
awards entered against the distributors and the steps taken to comply with them. ${ }^{107}$ Furthermore, the proceedings before the various arbitration boards will give the Government access to valuable information as to the situs of actual instances of restraint should the Division decide to inaugurate future suits. Thus a not inconsequential result of the decree will be the supplying of the Government with information about the mysteries of the industry otherwise rarely available. The knowledge of this by the defendants may itself exercise a prophylactic effect upon future abuse of power.

The three defendants which did not consent to the decree are now somewhat ambiguously situated, as they prepare to defend against the continuing Government suit. 108 Owning no theaters, the threat of divorcement means little to them should the Government win its case, and they therefore stand to lose much less than did the consenting defendants. They might even improve their competitive position if the larger producer-distributor organizations were deprived of their remunerative exhibition facilities. On the other hand, block booking is of great importance to both Universal and Columbia ${ }^{109}$ Both of these companies could ill afford the added expense of several new selling "seasons"; both might have to engage in extensive unprofitable financing to secure the additional working capital necessary if they were to accumulate five completed pictures prior to contracting for their exhibition. ${ }^{110}$ All three companies stand to gain sizable profits by operating on an annual contract basis, in the form of increased licensing by unaffiliated exhibitors desirous of securing an assured back-log of product and thus placing themselves in a better position to bargain for the various small blocks offered by the consenting producers. Consequently, it is understandable why the three unaffiliated defendants should have determined to remain aloof from the decree.

The Government, however, is not only faced with the dilemma of proceeding against the intransigent defendants or confessing the weakness of its original case, but has expressly obligated itself in the decree to secure selling restrictions on block booking and blind selling equivalent to those imposed upon the consenting parties. ${ }^{111}$ This may be difficult for the Government to achieve, for the remaining defendants appear to be in a good strategic position to meet any subsequent Government attack. They are unaffected by the integration problem and control too small a percentage of the business

107. Consent Decree $\$ 18$. All information secured is to be confidential with the Department of Justice.

108. Efforts to have the suit quashed as to the remaining defendants have bren overruled, and the case is expected to go to trial sometime in the spring of 1941. VAnrerr, Jan. 8, 1941, 5, col.5.

109. United Artists has rarely, if ever, utilized block booking, although they have at times pre-sold all of the pictures to be made by any one of their component producers. Amended Complaint, p. 40, \107.

110. See note 43 supra.

111. Consent Decree $\$ 12(a)$, (b). 
of the industry to substantiate any charge of monopoly. The amended complaint, however, charges defendants with conspiring with the large circuits to discriminate against the small independent exhibitors, ${ }^{112}$ and each separate defendant is charged with illegally restraining trade by entering into contracts imposing compulsory block booking and blind selling upon exhibitors. ${ }^{113}$ It is possible that the Government may secure the necessary evidence to show collusion between the defendants and the more powerful chains, and it is not inconceivable that the prosecution can persuade the Court to overrule Federal Trade Commission v. Paramount Pictures, ${ }^{114}$ and cleclare block booking and blind selling illegal per se.

Even should the Government be successful in its subsequent trial of the "little three," it is of course not certain that it could induce the court to grant more than an injunction against the illegal practices. ${ }^{115}$ Should their right to block booking be finally denied, however, the defendants might well agree to accept arbitration. Certainly blocks of five pictures with arbitration would seem preferable to retail licensing by individual features.

\section{ConCLusion}

The decree which has been approved is the product of negotiation and compromise by contesting parties, and therefore can hardly be expected to achieve a legislative standard of perfection. It is broad in scope and highly experimental in certain of its details so that evaluation of its merits can at best be only enlightened guesswork. Yet while the merits or evils of the various provisions must eventually prove themselves through experience in practice, a few generalizations may be made from this vantage point.

It would be unfortunate to judge the success or failure of the decree as a unit, for the decree has been aimed at more than one channel of restraint. Moreover, in the establishment of the grievance machinery of disinterested arbitration, the decree has achieved a technical advance in anti-trust enforcement which may prove of greater value than any of the provisions more particularly related to motion pictures. The provisions against clearance, run, and other forms of discrimination are weak only in those instances where they do not go far enough, and in the oversimplification in denoting circuit buying power as the sole cause of favoritism. The selling practices imposed by the decree, however, are of more questionable merit. Surely the possi-

112. Amended Complaint, p.77, $\llbracket 178$. This would seem to be in line with the definition of an illegal conspiracy found in Interstate Circtit v. United States, 306 U. S. 208 (1939).

113. Amended Complaint, p. 78, 1 (I 180-183.

114. 57 F. (2d) 152 (C. C. A. 2d, 1932). This might be overruled under the Sherman Act as a combination or conspiracy in restraint of trade between the corporation and the individual persons comprising its officers and directors, or as an illegal tying contract prohibited by $\S 3$ of the Clayton Act. 38 STAT. 731 (1914), 15 U.S.C. $\$ 14$ (1934).

115. See note 91 supra. 